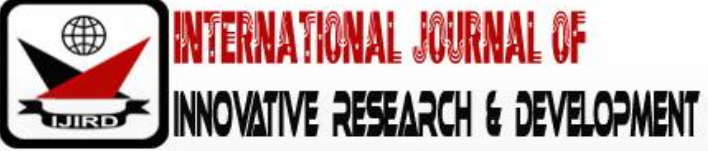

ISSN 2278 - 0211 (Online)

\section{Reflections of Government and Peer Group on Nigerian Students Behaviour to Basic Science and Technology}

\author{
Dr. Moses Olanrewaju Afuwape \\ Senior Lecturer, Department of Science and Technology Education, \\ Olabisi Onabanjo University, Ago-Iwoye, Nigeria \\ Adeyi Funmilayo Adeola \\ Higher Executive Officer, Department of Science and Technology Education, \\ Olabisi Onabanjo University, Ago-Iwoye, Nigeria
}

\begin{abstract}
:
Good governance is identified with patriotism, transparency, prudence, rule of law and sanctity of life. National Policy on Education (FRN, 2004) affirmed that education in Nigeria as an instrument "Par excellence" for affecting national development and the specific goal of basic education is government's way of realizing that part of national goals which "Basic Science and Technology" stand to achieve.

The study examined reflections of government and peer group on Nigerian students' behavior to Basic Science and Technology. The design of the study was survey type while the population comprised (50) Basic Science teachers and (450) public and private junior secondary school students in the selected Local Government Area in Ogbomoso Educational zone of Oyo State. Self-developed questionnaire on government and peer group factors were formed for data collection. The instrument was validated with a Cronbach Alpha Reliability Coefficient of 0.83 and 0.94 respectively while two research questions and two null hypotheses guided the study. The result were analyzed using frequency count, mean and simple percentage, while t-test statistics was used to test the hypotheses at 0.05 level of significance.

The result showed that Government failed to perform her responsibilities effectively in terms of provision of instructional materials, teachers' welfare, funding of schools, security, and poor school administration. All these have significant effect on Nigerian students and their peers' behavior towards Basic Science and Technology. Based on these findings, recommendations were made.
\end{abstract}

Keywords: Reflections, government, peer group and Nigerian students' behavior

\section{Introduction}

Science Education in Nigeria dates back to the pre-independence days. It is the training given to individuals in order to enable them appreciate their environment and become useful to themselves and the society at large. Anegbe and Adeoye (2006) affirmed that the Nigerian child is introduced to science right from the primary school. The essence is to enable the learner to develop interest in science, learn science, 'do' science and contribute effectively to the scientific and technological development of the nation. The foundation of science and technology is presented to the learner at the basic level of education in Nigeria. Basic education shall be of 9year education comprising 6 years of primary and 3 years of junior secondary education. It shall be free be and compulsory. It shall also include adult and non-formal education programme at primary and junior secondary education levels for the adults and out-of-school youths (FRN, 2014). It will be important to note that the administration of "Basic Education Programme" is monitored by the government.

Government is the people who control a country, region, or town and make decision about its laws and taxes; The role of government in provision of quality education cannot be overemphasized. Government is expected to create an enabling environment for effective teaching and learning through the provision of necessary infrastructure, facilities and qualified manpower (Abdullahi \& Abdullah, 2014). Good government is measured in result and performance but when record of poor result and performance is made, governance could be questionable. From research studies, poor performance has been attributed to factors such as lack of equipped laboratories, deficient libraries, as well as population explosions in schools. In order to achieve quality education in any country, there are eight dimensions of good schools, which include good finance, good governance and community links, good leadership and management, good teaching, good student outcomes, a good curriculum appropriate to the ages and needs of the students, good ethos, where learning, social responsibility and personal development are valued and a good environment, where best use is made of physical facilities and resources (David, 2011; Prasad \& Tata, 2003).

In addition to this, studies carried out by Onwioduokit (1996) and Olarewaju (1997) showed that insufficient manpower, lack of concentration during lessons, lack of commitment and motivation to work, lack of equipment, poor attitudes of students, poor understanding of concepts, inability to study well, neglect of assignment and pleasure seeking 
attitude contribute to low academic achievement. Okebukola in his lecture "Delivery of science education in Nigeria: putting the shoe on the right foot" emphasized the misplaced goals in science education in Nigeria, heaping the blame at the door step of the government, teachers and students. (Vanguard, March, 27th, 2014). For a dynamic society, government and committed citizens are factors.

A peer group consists of people or individuals that are within close ages for instance between age of one to four, The school serves as primary setting for the membership of peer group. Persons in a peer group be in the same class, or belong to the same sex with equal and common interactive style and close interaction as equals. It is generally observed that peer group has a lot of influence on students. This is seen from the role played by the peer group in the life and learning of a child. It is believed that students feel more comfortable and relaxed among fellow students. A child who is brilliant but is surrounded by dull friends may probably lose interest in learning. On the other hand, a peer group that is inclined to study would have positive effect on a dull member towards learning and thereby stimulate his/ her interest in learning. Peer pressure refers to the influence exerted by a peer group in encouraging a person to change his/her attitudes, values in order to conform to group norms (Kirk, 2000). While most educators believe that peer pressure has an influence on children's academic performance, Kirk (2000) observes that few studies have been done to prove this belief. Peer groups are an important socialization agent. The more subtle form of peer pressure is known as peer influence, and it involves changing one's behaviour to meet the perceived expectations of others (Burns \& Darling, 2002).

Bankole, E. T. and Ogunsakin, F. C. (2015) investigated the influence of peer group on the academic performance of secondary school students in Ekiti State. The result revealed that age, gender and religious difference do not matter in determining academic performance among secondary school students. The result further suggests that peer relationship, socialization, location, motivation and drug use have a great influence in determining academic performance of secondary school students. However, the comparative influence of peers' parents, home-setting and extra-curricular activities which are contextual variables that may differently influence academic performance were not taken into account in this study. The performance of students in science generally is a major concern to science educators. Aghyeneku in Sakiyo and Sofeme (2008) noted that students' performance in science subjects is low in both national and state examinations. A number of reasons can be identified to be accountable for the poor performance of students in sciences. These include the science curricula, teachers' methods of teaching, parents, government, lack of science facilities and others (Ahiakwo, 2003). Survey from schools (Ajayi, 2007) revealed that inadequacy of good instructional materials, equipment and laboratory facilities in the schools also negatively affect the effective learning of Physics in the schools. According to Ango (1990), students' poor performance in physics globally is basically due to failure to involve the students in the teaching learning activities right from the beginning of any new concept to be taught, lack of qualified teachers as well as experiences in teaching and unavailability and/ or insufficiency of materials in the laboratories. which is the responsibility of government to provide in order to facilitate teaching and learning of Basic Science and Technology.

To achieve the set objectives of Basic Science and Technology, student need to exhibit positive behaviour towards the subject. Students' behaviour is the way students behave or act. Such behaviour include: positive attitude, better interest, and good value judgement which are the variables of interest in this study. Attitude refers to predisposition to classify objects and events, to react to them with evaluative consistency. Studies in Basic Science have revealed that students have developed negative attitudes towards the subject (David,Okorn, Osam, Ekpo\& Fidelis, 2013) and many showed dismal performance in it (Afuwape \& Olatoye, 2004). Interest is behaviour. Interest is a feeling of wanting to know about or take part in something. Interest toward Basic Science is ability for student to have feelings or willingness to know about Basic Science. (Ifamuyiwa \& Akinsola, 2008 and Gbore \& Daramola, 2013).Njoku (2003) argued that interest and motivation among other variables are components of attitude which can be moderated through reinforcing learning and experience. Values are socially approved desires and goals that are internalized through the process of conditioning, learning or socialization and that become subjective preferences, standards and aspiration. Value focus on the judgement of what ought to be. This, according to Afuwape and Olatoye (2004), has prevented students from offering or performing well in the core science subjects at the Senior Secondary School level.

In addition to the modification of their behaviour due to the transition phase of their life, secondary school students also change their behaviour on account of many other factors that are external. Dupper (2010) maintains that students misbehave because there are mismatches between their needs and the socio-environmental factors. In conclusion, the study is hinged on how government of Nigeria and student peer group are influencing either positively or negatively the behaviour of Nigerian students to the Basic Science Technology.

\subsection{Purpose of the Study}

The purpose of this study is to reflect on the government and peer group and Nigerian student' behaviour to Basic Science and Technology.

\subsection{Research Questions}

- What are the Government's constraints to teaching of Basic Science and Technology.

- What is the students/ peer groups constraints to teaching of Basic Science and Technology'.

\subsection{Hypotheses}

- $\mathrm{HO}_{1}$ : There is no significant difference in the government constraints to the teaching of Basic Science and Technology in private and public secondary schools in Oyo State

- $\mathrm{HO}_{2}$ : There is no significant difference in the students/ peer group constraints to the teaching of Basic Science and Technologyin private and public secondary schools in Oyo State. 


\section{Methodology}

This research adopted a survey design type. This will help to provide information about the neutrality of occurrence or characteristics.

\subsection{Population of the Study}

The population for the study consists of Education officers, Basic Science teachers and students in public and private junior secondary schools in Ogbomoso Educational Zone of Oyo State. The sample involved four hundred and fifty (450) Upper Basic Level (Junior Secondary school II) students in both public and private junior secondary schools, all Basic science teachers in selected public and private Junior Secondary schools and Local Education Officers in Ogbomoso Educational Zone of Oyo State, Nigeria

\subsection{Instrument}

Self-designed questionnaires, entitled Government Factor Questionnaire. (GFQ) and Students/ Peer group factor Questionnaire. (SPGFQ) - Forms I and II for teachers (who taught Basic Science Technology in 2017/2018 academic session) and junior secondary school three students, respectively, were employed for data collection. The twenty-five items focused on government factor and twenty items focused on students/ peer group factor. The Cronbach's alpha of the questionnaire was 0.83 for government factor questionnaire and 0.94 for students/ peer group factor questionnaire respectively.

\subsection{Data Collection and Analysis}

The researcher personally administered the questionnaires in selected schools of the selected Local Government Area of Ogbomoso Educational Zone where pilot study was conducted. She employed the help of Basic Science and Technology teachers to serve as research assistants in administering the questionnaires to respondents. A total of four weeks were used for the administration and collection of the questionnaires. All the questionnaires administered were retrieved. However, questionnaires for four hundred and fifty (450) schools were properly filled and deemed adequate for analysis. The data resulting from the coding of the instrument of the demographic items were then subjected to frequency count, mean, simple percentage and t-test statistical analysis.

\section{Results}

The results of the study are presented in the tables below.

\subsection{Research Question 1}

What are the governments constrains to teaching of Basic Science and Technology.

\begin{tabular}{|c|c|c|c|c|c|c|c|c|c|}
\hline $\mathbf{S} / \mathbf{N}$ & ITEMS & $\begin{array}{l}\text { Mean of } \\
\text { SA (PUB. } \\
\text { SCHL) }\end{array}$ & $\begin{array}{l}\text { Mean of } \\
\text { SD (PUB. } \\
\text { SCHL }\end{array}$ & $\begin{array}{l}\text { Mean of } \\
\text { SA (PRV. } \\
\text { SCHL) }\end{array}$ & $\begin{array}{l}\text { Mean of } \\
\text { SD (PRV. } \\
\text { SCHL) } \\
\end{array}$ & $\begin{array}{l}\text { \% of SA } \\
\text { (PUB. } \\
\text { SCH }\end{array}$ & $\begin{array}{l}\text { \% OF SD } \\
\text { (PUB. SCH }\end{array}$ & $\begin{array}{c}\text { \% OF SA } \\
\text { (PRIV SCH) }\end{array}$ & $\begin{array}{l}\text { \% OF SD } \\
\text { (PRIV. } \\
\text { SCHL) }\end{array}$ \\
\hline 1 & $\begin{array}{c}\text { Non provision of } \\
\text { instructional materials for } \\
\text { the teaching of Basic } \\
\text { science and technology }\end{array}$ & 22 & 3 & 18 & 7 & 88 & 12 & 72 & 18 \\
\hline 2 & $\begin{array}{l}\text { Teachers' welfare is not } \\
\text { adequately taking care of } \\
\text { in terms of salary, } \\
\text { motivation, incentives and } \\
\text { promotion. }\end{array}$ & 18 & 7 & 20 & 5 & 72 & 28 & 80 & 20 \\
\hline 3 & $\begin{array}{l}\text { Failure of the government } \\
\text { to fund both public and } \\
\text { private schools. }\end{array}$ & 24 & 1 & 22 & 3 & 96 & 4 & 88 & 12 \\
\hline 4 & $\begin{array}{l}\text { Politics and societal } \\
\text { activities (insurgence) is } \\
\text { another major } \\
\text { government constraint to } \\
\text { teaching of Basic science. }\end{array}$ & 18 & 7 & 18 & 7 & 72 & 28 & 72 & 28 \\
\hline 5 & $\begin{array}{c}\text { Poor school } \\
\text { administration in terms of } \\
\text { school supervision, in- } \\
\text { service training for basic } \\
\text { science teachers, } \\
\text { organizing seminars and } \\
\text { workshop and appointing } \\
\text { unskilled teachers for } \\
\text { Basic science and } \\
\text { technology }\end{array}$ & 19 & 6 & 21 & 4 & 76 & 24 & 84 & 16 \\
\hline
\end{tabular}

Table 1: Means and Percentages of Respondents on Government Constraints 
Based on this study, Table 1 indicates that the major government constraints in the teaching of Basic science and technology are as follows:

- Non provision of instructional materials for the teaching of Basic Science and Technology. The percentage of respondents that agreed on non-provision of instructional materials is $88.00 \%$ in public schools and $72.00 \%$ in private schools

- Teachers' welfare is not adequately taken care of in terms of salary, motivation, incentives and promotion. The percentage of respondents that agreed on this in the public schools is $72.00 \%$ while in private schools is $80.00 \%$.

- Failure of the government to fund both public and private schools adequately is another constraint. The percentage of respondents that agreed on this in the public schools is $96.00 \%$ while that of private schools is $88.00 \%$.

- Politics and societal activities (insurgence) is another major government constraint to teaching of Basic Science. Percentage of those who agreed in public schools is $72.00 \%$ and also in private school $72.00 \%$ respectively.

- Poor school administration in terms of school supervision, in-service training for basic science teachers, organizing seminars and workshop and appointing unskilled teachers for Basic Science and Technology is another constraint. Percentage of those who agreed on this in public schools is $84.00 \%$ while that of private schools is $76.00 \%$.

\subsection{Research Question 2}

What are the students/ peer groups constrains to teaching of Basic Science and Technology?

Based on the result in this study, the result revealed that the respondents believe that they can do well (self- efficacy) in Basic Science and Technology in both public and private schools provided qualified teachers are provided. The table further revealed that the respondents (that is students) have interest in studying Basic Science and Technology provided that well equipped laboratory and standard library are in place.

\subsection{Testing of Hypotheses}

- $\mathrm{HO}_{1}$ : There is no significant difference in the government constraints to the teaching of Basic science and technology in public and private secondary schools in Oyo State.

\begin{tabular}{|c|c|c|c|c|c|c|c|c|}
\hline \multicolumn{2}{|c|}{} & \multicolumn{2}{c|}{$\begin{array}{c}\text { Levene's Test for } \\
\text { Equality of Variances }\end{array}$} & \multicolumn{6}{c|}{ t-test for Equality of Means } \\
\cline { 3 - 9 } \multicolumn{2}{|c|}{} & $\mathrm{F}$ & Sig. & $\mathrm{T}$ & $\mathrm{df}$ & $\begin{array}{c}\text { Sig. (2- } \\
\text { tailed) }\end{array}$ & Mean Difference & $\begin{array}{c}\text { Std. Error } \\
\text { Difference }\end{array}$ \\
\hline GQ1 & $\begin{array}{c}\text { Equal variances } \\
\text { assumed }\end{array}$ & 1.144 & 0.29 & -1.22 & 48 & 0.228 & -0.28 & 0.2292 \\
\cline { 2 - 9 } & \multicolumn{2}{|c|}{ Equal variances not assumed } & -1.22 & 43.287 & 0.228 & -0.28 & 0.2292 \\
\hline
\end{tabular}

Table 2: Independent Sample Test for Government Factor

The p-value (0.228) is greater than 0.05 , hence, we fail to reject Ho and conclude that there is no significance difference in the government constraints to the teaching of Basic Science and Technology in public and private secondary schools in Oyo State.

- $\mathrm{HO}_{2}$ : There is no significant difference in the students/ peer group constraints to the teaching of Basic Science and Technology in public and private secondary schools in Oyo State.

\begin{tabular}{|c|c|c|c|c|c|c|c|c|c|c|}
\hline & \multicolumn{2}{|c|}{$\begin{array}{l}\text { Levene's Test } \\
\text { for Equality of } \\
\text { Variances }\end{array}$} & \multicolumn{8}{|c|}{ t-test for Equality of Means } \\
\hline & \multirow[t]{2}{*}{$\mathrm{F}$} & \multirow[t]{2}{*}{ Sig. } & \multirow[t]{2}{*}{$\mathrm{T}$} & \multirow[t]{2}{*}{ Df } & \multirow[t]{2}{*}{$\begin{array}{l}\text { Sig. (2- } \\
\text { tailed) }\end{array}$} & \multirow[t]{2}{*}{$\begin{array}{c}\text { Mean } \\
\text { Difference }\end{array}$} & \multirow[t]{2}{*}{$\begin{array}{l}\text { Std. Error } \\
\text { Difference }\end{array}$} & \multicolumn{3}{|c|}{$\begin{array}{l}\text { 95\% Confidence Interval of the } \\
\text { Difference }\end{array}$} \\
\hline & & & & & & & & & Lower & Upper \\
\hline $\begin{array}{l}\text { Student } \\
\text { Factor }\end{array}$ & $\begin{array}{c}\text { Equal } \\
\text { variances } \\
\text { assumed }\end{array}$ & 3.694 & 0.055 & -1.824 & 448 & 0.069 & -0.11111 & 0.06091 & -0.23081 & 0.00859 \\
\hline & \multicolumn{3}{|c|}{$\begin{array}{l}\text { Equal variances not } \\
\text { assumed }\end{array}$} & -1.824 & 437.554 & 0.069 & -0.11111 & 0.06091 & -0.23082 & 0.0086 \\
\hline
\end{tabular}

Table 3: Independent Samples Test

The p-value (0.069) is greater than 0.05 , hence, we fail to reject Ho and conclude that there is no significant difference in the students/ peer group constraints to the teaching of Basic Science and Technology in public and private secondary schools in Oyo State.

\section{Discussions}

The findings of this study revealed that there is no significant different in government constraints to the teaching of Basic Science and Technology in public and private schools in Oyo State. The result of the research question revealed 
that the respondent in public and private schools agreed that Non provision of instructional materials for the teaching of Basic Science and Technology, politics and societal activities (insurgency) and poor school administration in terms of school supervision, in-service training for basic science teachers, organizing seminars and workshop and appointing unskilled teachers on Basic Science and Technology are the major government constrains to the teaching of Basic Science and Technology in Oyo State.

The above views are in agreement with the view of Prasad \& Tata,(2003),Akindutire(2010),David, 2011, Okebukola (2014), Abdullahi\& Abdullah, (2014); that government is expected to create an enabling environment for effective teaching and learning to take place through the provision of necessary infrastructure, facilities and qualified manpower. The finding above x-ray another major area of government constra into the teaching of basic science and technology which is teachers' welfare that is not adequately taken care of in terms of salary, motivation, incentives and promotion. This finding is in agreement with the view of Mohammal (2011),Smith and Glenn, (2014) Teachers are the most critical component of any system of education. How well they teach depends on motivation, qualification, experience, training, aptitude and a mass of other factors, not the least of these being the environment and management structures with in which they perform their role. Teachers must be seen as part of the solution, not part of the problem. Poor pay, low status and morale are key causes of poor productivity and corrupt behavior in the public sector.

\section{Conclusion}

It is the responsibilities of Nigerian government to ensure literacy of citizens all over the globe. Government has to invest in education so as to facilitate the achievement of the nation's educational goals. The effort of government in education has a significant effect on Nigerian students' behaviour on Basic Science and Technology. Government and policy makers should, therefore ensure that junior secondary schools across the nation are provided with necessary and sufficient facilities such as adequate number of skilled teachers that can successfully handle the teaching of Basic Science Technology to the satisfaction of the students, ensure provision of instructional materials for teaching Basic Science Technology, ensure provision of maximum security, curb insurgency and ensure good school administration. These can go a long way in changing the negative behaviour of students and their peers toward Basic Science and Technology.

\section{References}

i. Abdullahi and Abdullahi (2014). The political will and Quality Basic Education.Journal of power, politics \& Governance June 2014, Vol, 2, No. 2 pp. 75-100

ii. Afuwape, M.O. (2017). Taking Proactive National Development in its Strides: A Speculative Peep at Emerging Trends in Science and Technology Education as a Sure Panacea. British Journal of Education.

iii. Afuwape, M. O. \&Olatoye, R. A. (2004). Students Integrated Science Performance as a Predictor of Later Performance in Biology, Chemistry and Physics. Journal of Science Teachers Association of Nigeria (JSTAN,) 39 (1 \&2) 11 - 16. Retrieved on 7/ 6/2013 from http:/ / stanonline.org/ journal/ pdf/ VOLUME\%2039,\%20NUMBERS\%201\%20\& \%202\%20\%28DEC.\%202004\%29.pdf

iv. Ango, M. (1990). Basic science laboratory with practical suggestions and procedures. Lagos: Hinders

v. SAhiakwo, O. (2003). Science, science education and scientific literacy. [Online] Available:

vi. www.ccsenet.org/ http/:www.unn.edu.net/ DEPT/ dept-scienceedu.

vii. Ajayi, P. O. (2007). Evaluation of the implementation of senior secondary school physics curriculum in south west Nigeria (Unpublished Ph. D thesis). University of Ado-Ekiti, Nigeria.

viii. Adejumobi, F. T. \&Ojikutu, R. K. (2013) School climate and teacher job performance in Lagos state Nigeria

ix. Akindutire, I.O. (2010) Teacher education in democratic Nigeria: challenges and the way forward. South- West Journal of Teacher Education, 3, 107-128

x. Okebukola, P.A. O. (1997)Forty Years of Intervention of the Science Teachers Association of Nigeria (STAN) and the Road Ahead. 40th Anniversary Conference Proceeding.

xi. Gbore, L. O. and Daramola, C. A. (2013). Relative Contributions of selected Teachers' variable and Students' attitude toward Academic Achievement in Biology among Senior Secondary School Students in Ondo State, Nigeria. Current Issue in Education 16 (1)1-11

xii. Ifamuyiwa, S.A. And Akinsola, M. K ( 2008 ) 'Improving Senior Secondary School Students' attitude toward Mathematics through Self and Cooperative Instructional Strategies' International Journal of Mathematical Education in Science and Technology, 39; (5) 569-585

xiii. Njoku, Z. C. (2003). Development and Preliminary Validation of a Scale for the Assessment of Students Interest in O’ level Practical Chemistry Activities Journal of the Science Teachers Association of Nigeria Vol. 38 (1\&2) 64-70 